Subscriber access provided by Caltech Library

\title{
Article
}

\section{Reaction mechanism and kinetics for ammonia synthesis on the Fe(111) Surface}

Jin Qian, Qi An, Alessandro Fortunelli, Robert J. Nielsen, and William A. Goddard

J. Am. Chem. Soc., Just Accepted Manuscript • Publication Date (Web): 27 Apr 2018

Downloaded from http://pubs.acs.org on April 27, 2018

\section{Just Accepted}

"Just Accepted" manuscripts have been peer-reviewed and accepted for publication. They are posted online prior to technical editing, formatting for publication and author proofing. The American Chemical Society provides "Just Accepted" as a service to the research community to expedite the dissemination of scientific material as soon as possible after acceptance. "Just Accepted" manuscripts appear in full in PDF format accompanied by an HTML abstract. "Just Accepted" manuscripts have been fully peer reviewed, but should not be considered the official version of record. They are citable by the Digital Object Identifier (DOI®). "Just Accepted" is an optional service offered to authors. Therefore, the "Just Accepted" Web site may not include all articles that will be published in the journal. After a manuscript is technically edited and formatted, it will be removed from the "Just Accepted" Web site and published as an ASAP article. Note that technical editing may introduce minor changes to the manuscript text and/or graphics which could affect content, and all legal disclaimers and ethical guidelines that apply to the journal pertain. ACS cannot be held responsible for errors or consequences arising from the use of information contained in these "Just Accepted" manuscripts. 


\title{
Reaction Mechanism and Kinetics for Ammonia Synthesis on the Fe(111) Surface
}

\author{
Jin Qian ${ }^{1 \perp}$, Qi An ${ }^{1,2^{\perp}}$, Alessandro Fortunelli ${ }^{1,3}$, Robert J. Nielsen ${ }^{1}$, \\ William A. Goddard III ${ }^{1, *}$ \\ ${ }^{1}$ Materials and Process Simulation Center (MSC), \\ California Institute of Technology, Pasadena, California 91125, United States \\ ${ }^{2}$ Department of Chemical and Materials Engineering, \\ University of Nevada, Reno, Reno, Nevada 89577, United States \\ ${ }^{3}$ CNR-ICCOM, Consiglio Nazionale delle Ricerche, Pisa, 56124, Italy \\ ${ }^{\perp}$ J.Q. and Q.A. contributed equally to this work. \\ *wag@,wag.caltech.edu; ORCID:0000-0003-0097-5716
}

\begin{abstract}
The Haber Bosch industrial process for synthesis of ammonia $\left(\mathrm{NH}_{3}\right)$ from hydrogen $\left(\mathrm{H}_{2}\right)$ and nitrogen $\left(\mathrm{N}_{2}\right)$, produces the millions of tons of ammonia gas annually needed to produce nitrates for fertilizers required to feed the earth's growing populations. This process has been optimized extensively, but it still uses enormous amounts of energy ( $2 \%$ of the world's supply), making it essential to dramatically improve its efficiency. To provide guidelines to accelerate this improvement, we used quantum mechanics $(\mathrm{QM})$ to predict reaction mechanisms and kinetics for $\mathrm{NH}_{3}$ synthesis on $\mathrm{Fe}(111)$ - the best Fe single crystal surface for $\mathrm{NH}_{3}$ synthesis. We predicted the free energies of all reaction barriers for all steps in the mechanism and built these results into a kinetic Monte Carlo model for predicting steady state catalytic rates to compare with single-crystal experiments at $673{ }^{\circ} \mathrm{K}$ and $20 \mathrm{~atm}$. We find excellent agreement with a predicted turnover frequency (TOF) of $17.7 \mathrm{sec}^{-1}$ per $2 \times 2$ site $\left(5.3 \times 10^{-9} \mathrm{moles} / \mathrm{cm}^{2} / \mathrm{sec}\right)$ compared to $\mathrm{TOF}=10 \mathrm{sec}^{-1}$ per site from experiment.
\end{abstract}

Key words for indexing: Haber-Bosch; Density Functional Theory (DFT), PBE-D3 functional, reaction barriers, kinetic Monte Carlo.

\section{Introduction}

The invention of the Haber-Bosch process for converting nitrogen gas $\left(\mathrm{N}_{2}\right)$ and hydrogen gas $\left(\mathrm{H}_{2}\right)$ into the ammonia $\left(\mathrm{NH}_{3}\right)$ needed to generate the nitrates for the fertilizers underlying the agricultural revolution that feeds the world, is one of the greatest advances from scientific research. Millions of tons of $\mathrm{NH}_{3}$ are produced each year ${ }^{1}$ for agricultural and industrial purposes. Efficiency of up to $70 \%{ }^{2}$ has been achieved with commercially available iron based catalysts ${ }^{3}$ and with ruthenium-based catalysts under lab settings ${ }^{4}$. Ruthenium-based catalysts are more active than iron-based ones ${ }^{5,6}$, and have been recently further developed. ${ }^{7,8}$ However, rutheniumbased catalysts suffer from environmental problems due to ruthenium's scarce abundance in Earth's crust, high cost, together with its toxicity when in the form of compounds ${ }^{9}$, so that the industrial Haber-Bosch process is still based on iron catalysts. The industrial Haber-Bosch process requires drastic conditions of temperature $\left(700^{\circ} \mathrm{K}-850^{\circ} \mathrm{K}\right)$ and pressure $(50-200 \mathrm{~atm})$, 
consuming $2 \%$ of the world's power, ${ }^{3,5,10-12}$ which has motivated repeated attempts to improve the efficiency of Fe catalyst. ${ }^{5}$

In order to provide a basis for making more rapid progress in such improvements, we want to use QM to determine the reaction mechanism and rates to help guide the search for improvements. In order to validate the QM predictions, we need to compare to experiments on well characterized surfaces. Fortunately, Somorjai et $\mathrm{al}^{13}$ reported comprehensive investigations of the rates for $\mathrm{NH}_{3}$ synthesis on Fe single crystals to which we can compare directly. Somorjai et al considered a pressure of $20 \mathrm{~atm}$ and temperatures in the range of 638 to $723^{\circ} \mathrm{K}$, to determine the rates of ammonia formation. For $673^{\circ} \mathrm{K}$ they found relative rates of 418: 25: 1 for $\mathrm{Fe}(111)$, $\mathrm{Fe}(100)$, and $\mathrm{Fe}(110)$ surfaces, respectively. In another study ${ }^{14}$, they concluded that $\mathrm{C} 7$ sites (Fe atoms with seven nearest neighbors) are the most active in iron ammonia synthesis catalysts. Such sites involve the top three layers of $\mathrm{Fe}(111)$ exposed to the reactant gases, rationalizing the reactivity of $\mathrm{Fe}(111)>\mathrm{Fe}(100)>\mathrm{Fe}(110)$. Somorjai showed that small amounts of $\mathrm{K}$ promote the catalysis increasing the rates by a factor of two. However the location of the $\mathrm{K}$ in the catalyst is not known, so we will compare to Somorjai results for the most active $\mathrm{Fe}(111)$ bare surface without $\mathrm{K}$ or other promoters.

We report here QM calculations on the 26 surface adsorbate configurations important in the full reaction mechanism including the free energy barriers that determine the rates for the 17 steps that we find to play an important role in the catalysis under Somorjai conditions. Then we use these predicted rates in a self-consistent kinetic Monte Carlo (kMC) model to predict the steady state rates of all the reaction steps to obtain the turn over frequency (TOF) for the Somorjai single crystal conditions. At $673 \mathrm{~K}$ and $20 \mathrm{~atm}$ pressure, we predict $\mathrm{TOF}=17.7 \mathrm{sec}^{-1}$ per $2 \times 2$ site $\left(5.3 \times 10^{-9}\right.$ moles/sec- $\left.\mathrm{cm}^{2}\right)$, which is in excellent agreement with the experimental TOF $=9.7 \mathrm{sec}^{-1}$. This validates our modeling results, providing the basis for using theory to help design improved catalytic systems.

\section{Methods}

For these QM studies we use the Perdew-Burke-Ernzerhof (PBE) flavor of Density Functional theory (DFT). including the D3 (Becke Johnson) ${ }^{15}$ empirical corrections for long range London dispersion (van der Waals attraction). ${ }^{16}$ The reason is that this level of QM has been validated recently for several systems. Thus reference ${ }^{17}$ carried out systematic studies for the oxygen reduction reaction $\left(\mathrm{ORR}, \mathrm{O}_{2}+\right.$ protons $\rightarrow \mathrm{H}_{2} \mathrm{O}$ ) on $\mathrm{Pt}(111)$ using the same PBE-D3 level as in this paper. Including 5 layers of explicit solvent in QM metadynamics on all reaction steps, comparisons could be made to experimental activation barriers for two values of the external potential. In both cases the calculated activation barriers were within $0.05 \mathrm{eV}$ of the experiment.

For the $\mathrm{CO}$ reduction reaction on $\mathrm{Cu}(100)$ the same level of theory obtains an activation energy within $0.05 \mathrm{eV}$ of experiment. ${ }^{18-21}$ This same level of theory has also led to similar accuracy for the oxygen evolution reaction on $\mathrm{IrO}_{2}{ }^{22}$ and for onset potentials on $\mathrm{Cu}(111){ }^{23-25}$

This is not a guarantee that PBE-D3 will work as well for Fe, where the presence of unpaired spins could cause problems, but it provides a reasonable starting point. Indeed, the accuracy compared to experiment seems to be comparable to these other cases. 
Indeed, we carried out exactly the same set of calculations at the PBE level without D3 (results in the SI) and find TOF=89.3 compared to 17.7 for PBE-D3 and 9.7 experiment. This indicates that for this system PBE-D3 provides better accuracy than pure PBE.

All calculations were carried out with the $\mathrm{VASP}^{26}$ software package. We established that an energy cutoff of $400 \mathrm{eV}$ leads to converged forces. The K-point sampling was chosen to be $4 \mathrm{x} 4$ $\mathrm{x}$ 1. All calculations include spin-polarization.

\subsection{Small Gas Molecules}

Calculations for the gas phase molecules used the PBE functional (as implemented in Jaguar) with the D3 empirical correction for London dispersion. ${ }^{15,27-29}$ Free energy corrections including enthalpy $(\mathrm{H})$, entropy (S), and zero-point energy (ZPE) from Jaguar calculations are included in Supplemental Information (SI).

To obtain the total free energy, $\mathrm{G}=\mathrm{H}-\mathrm{TS}$, for the gas molecules at temperature $\mathrm{T}$, we add to the DFT electronic energy (E), the zero-point energy (ZPE) from the vibrational levels (described as simple harmonic oscillators), and the specific heat corrections in the enthalpy from 0 to T. The entropy (S), as a sum of vibrational, rotational and translational contributions, are evaluated from the same levels. To correct the free energy for pressure, we assume an ideal gas and add $\mathrm{RT}^{*} \ln \left(\mathrm{P}_{2} / \mathrm{P}_{1}\right)$ with a reference pressure of $\mathrm{P}=1 \mathrm{~atm}$.

The Free energy changes $(\delta \mathrm{G})$ for the overall Haber Bosch reaction $\mathrm{N}_{2}+3 \mathrm{H}_{2} \Rightarrow 2 \mathrm{NH}_{3}$ under various conditions are calculated as

$\delta \mathrm{G}=2 * \mathrm{E}\left(\mathrm{NH}_{3}\right)+2 * \mathrm{ZPE}\left(\mathrm{NH}_{3}\right)+2 * \mathrm{H}\left(\mathrm{NH}_{3}\right)-2 \mathrm{~T} * \mathrm{~S}\left(\mathrm{NH}_{3}\right)-$

$\left[\mathrm{E}\left(\mathrm{N}_{2}\right)+3 * \mathrm{E}\left(\mathrm{H}_{2}\right)+\mathrm{ZPE}\left(\mathrm{N}_{2}\right)+3 * \mathrm{ZPE}\left(\mathrm{H}_{2}\right)+\mathrm{H}\left(\mathrm{N}_{2}\right)+3 * \mathrm{H}\left(\mathrm{H}_{2}\right)-\mathrm{T} * \mathrm{~S}\left(\mathrm{~N}_{2}\right)-3 \mathrm{~T} * \mathrm{~S}\left(\mathrm{H}_{2}\right)\right]$

The pressure dependence is added using $\mathrm{RT}^{*} \ln \left(\mathrm{P}_{2} / \mathrm{P}_{1}\right)$, 5atm and $15 \mathrm{~atm}$ for $\mathrm{N}_{2}$ and $\mathrm{H}_{2}$ respectively. We calculate $\delta \mathrm{G}$ is $-0.52 \mathrm{eV}$ for the reaction under $673^{\circ} \mathrm{K}$, and $20 \mathrm{~atm}$ total pressure, which can be compared with $\delta \mathrm{G}=-0.02 \mathrm{eV}$ at $700^{\circ} \mathrm{K}$ and $5: 15: 1$ atm $\mathrm{N}_{2}, \mathrm{H}_{2}$ and $\mathrm{NH}_{3}$, respectively, from experiment. ${ }^{30} \mathrm{We}$ calculate $\delta \mathrm{G}$ is $-1.22 \mathrm{eV}$ for the reaction under $673^{\circ} \mathrm{K}$, 5atm: 15atm: 1.5 torr for $\mathrm{N}_{2}, \mathrm{H}_{2}$, and $\mathrm{NH}_{3}$ respectively.

\subsection{Surface Optimization}

The PBE-D3(BJ) level of DFT leads to a calculated lattice parameter of a $=2.807 \AA$ for the bulk Fe bcc structure at $0^{\circ} \mathrm{K}$, slightly smaller than the experimental value $2.866 \AA$ at $298^{\circ} \mathrm{K} .{ }^{31}$ This level of DFT predicts a magnetic moment for bulk Fe of $2.23 \mu \mathrm{B}$ in excellent agreement with the experimental value, $2.22 \mu \mathrm{B} .^{31}$

For calculating the surface chemistry, we selected the (111) surface which Somorjai showed to be the most active catalytically. For these DFT calculations we use a two-dimensional periodic slab with six layers of Fe atoms each of which consists of a $(2 \times 2)(6.912 \AA \times 8.276 \AA)$ unit cell (4 surface Fe per cell). We include $15 \AA$ of vacuum in the $\mathrm{z}$ direction to minimize possible interactions between the replicated cells. The top five layers are relaxed while the bottom layer is kept fixed at the optimum geometry calculated for bulk Fe.

The vibrational frequencies for free energy calculations are calculated by allowing the adsorbed molecules and the top 3 layers of Fe to relax, with the bottom two layers fixed. For these phonon calculations we used $10^{-6} \mathrm{eV}$ energy convergence threshold to obtain reliable phonon frequencies (no negative eigenvalues.) To obtain the Free energy, G=H-TS, for the various equilibrium 
configurations, we used density functional perturbation theory (DFPT) to calculate the phonon density of states, which was used to calculate the ZPE, the temperature correction to the enthalpy, and the vibrational contributions to the entropy. An identical procedure was used for the transition states. We note that some of the frequencies correspond to hindered translational or rotational modes, for which the harmonic oscillator description is less accurate. In these cases, namely $\mathrm{NH}_{3}$ and $\mathrm{N}_{2}$ desorption calculations, we use ZPE corrections only ${ }^{32-34}$.

\subsection{Transition States}

Transition state searches used the climbing image NEB method in the VASP-VTST code. ${ }^{35}$ Here the initial and final states geometries were minimized first. Then three intermediate images were optimized, excluding initial and final images. An additional NEB climbing-image calculation was performed to obtain the final value of the barrier. The climbing NEB method generates a true transition state, as we confirmed by performing vibrational frequency calculations showing a single negative curvature in the Hessian. Dimer calculations ${ }^{36-37}$ were performed whenever extra imaginary frequencies were found in the NEB transition state image.

\subsection{Surface sites}

The adsorption sites for the various species $\mathrm{H}, \mathrm{N}, \mathrm{NH}, \mathrm{NH}_{2}, \mathrm{NH}_{3}$ calculated here are consistent with previous experimental ${ }^{38}$ and DFT results ${ }^{39-41}$. The Fe(111) surface has four types of adsorption sites: top (T), bridge (B), 3-fold-shallow (S), and 3-fold-deep (D), with top/shallow (TS), and top-Shallow-deep (TSD) intermediate sites, as shown in Figure 1.

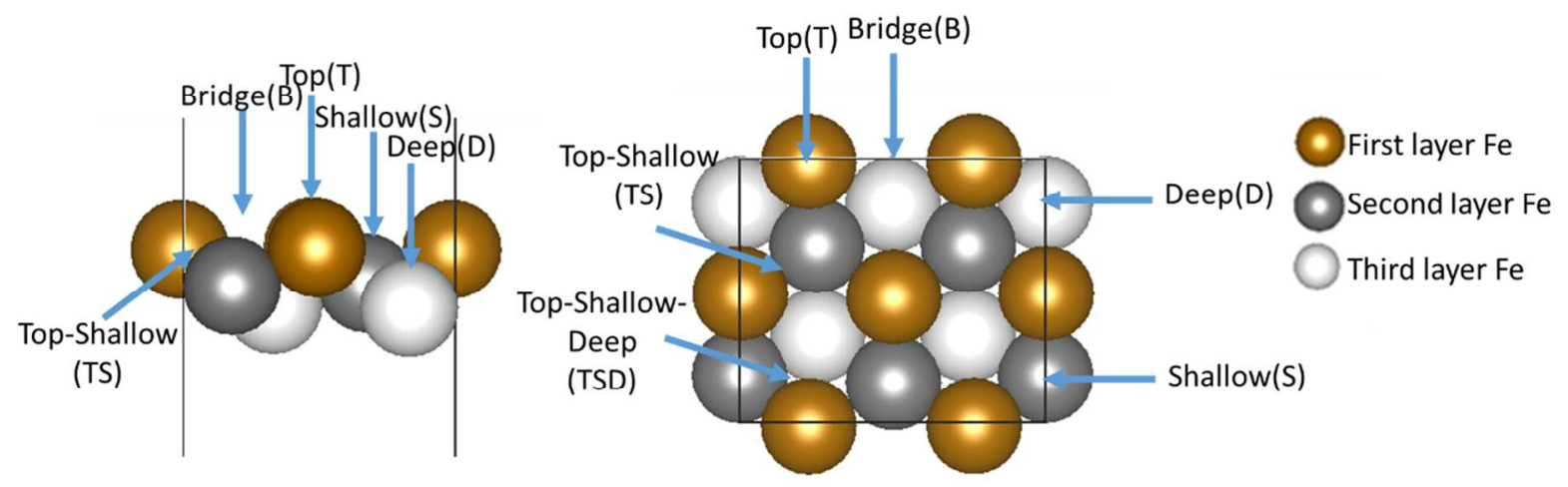

Figure 1. Structure of the Fe(111) surface with various surface adsorption sites noted. Bronze spheres represent the top layer, dark grey spheres represent the second layer, while white spheres are third layer Fe atoms. Multiple adsorption sites are labeled from both top and side views, including B, T, S, D, TS, and TSD sites. This figure shows only 3 of the 6 layers used in the calculations.

We find generally that

- H prefers the TS site between a top Fe and a $2^{\text {nd }}$ layer Fe or the TSD site between Fe on all 3 layers

- $\mathrm{N}$ prefers the $\mathrm{B}$ site,

- $\mathrm{NH}$ prefers the $\mathrm{BD}$ site, with $\mathrm{N}$ sitting on the bridge(B) site, but $\mathrm{NH}$ pointing sideways toward the D site

- $\mathrm{NH}_{2}$ prefers the TS site between a top $\mathrm{Fe}$ and a $2^{\text {nd }}$ layer Fe. 
- $\mathrm{NH}_{3}$ prefers the $\mathrm{T}$ site.

but as shown below in Fig. 3 occupation of other sites sometimes shifts the minima.

\section{Energy landscape. The most favorable pathways for converting $3 \mathrm{H}_{2}+\mathrm{N}_{2}$ to $2 \mathrm{NH}_{3}$, with illustrations for $\mathrm{T}=673^{\circ} \mathrm{K}$ and $\mathrm{p}=20 \mathrm{~atm}$}

We carried out DFT calculations including various numbers of $\mathrm{H}, \mathrm{N}, \mathrm{NH}, \mathrm{NH}_{2}, \mathrm{NH}_{3}$ molecules bound to the various stable sites for a $2 \times 2$ supercell of the (111) surface. For each combination of sites, we calculated the vibrational frequencies to obtain the free energy at the operational temperature. Then we calculated the reaction barriers for the various reaction pathways. We then used these values to find reaction sequences with lowest overall free energy barrier for the full process of converting one $\mathrm{N}_{2}$ and three $\mathrm{H}_{2}$ to form two $\mathrm{NH}_{3}$.

For a total pressure $\mathrm{P}=20$ atm under stoichiometric conditions and $\mathrm{T}=673^{\circ} \mathrm{K}$, we find that the lowest free energy for an equilibrium in which no reactions are allowed is the $3 \mathrm{~N}_{-} \mathrm{NH}_{2}$ configuration shown in Figure 2. Thus, prior to allowing reactions to proceed, the equilibrium condition on the $\mathrm{Fe}(111)$ surface in our $2 \times 2$ model would be predominantly the $3 \mathrm{~N}_{-} \mathrm{NH}_{2}$ configuration. We take the free energy of this state as our reference point, with $\mathrm{G}=0$. However, as discussed in section 4 , the steady state kinetic process producing $\mathrm{NH}_{3}$ leads to different distributions of states that depend on the $\mathrm{NH}_{3}$ pressure assumed for the steady state.

We examined the barriers between all the states connecting though reactions of $\mathrm{N}_{2}$ and $\mathrm{H}_{2}$ at various sites, leading finally to the energy landscape in Figure 2, involving 26 intermediates and leading to the lowest maximum barriers. We include in Figure 2 the states that we found to be important for the steady state kinetics as described in section 5 . We confined our calculations to the $2 \times 2$ supercell.

The favorable path selected in Fig. 2 includes the following transitions (all energies in eV)

1. 3N_ $\mathrm{NH}_{2}+3 \mathrm{H}_{2}$ gas $+\mathrm{N}_{2}$ gas; $\mathrm{G}=0$ at $\mathrm{T}=673^{\circ} \mathrm{K}$ and $\mathrm{p}=20 \mathrm{~atm}$

2. $=>3 \mathrm{~N} \_\mathrm{NH}_{2} \_2 \mathrm{H}\left(\mathrm{H}_{2}\right.$ gas $\left.\rightarrow \mathrm{H}^{*}+\mathrm{H}^{*}\right) \mathrm{G}=0.57$, where we expect a barrier of $0.57 \mathrm{eV}$.

3. $=>3 \mathrm{~N}_{-} \mathrm{NH}_{3} \mathrm{H}\left(\mathrm{H}^{*}+\mathrm{NH}_{2} * \rightarrow \mathrm{NH}_{3} *\right) \mathrm{G}=0.30$ and $\mathrm{G}+=1.47$

4. $\Rightarrow>3 \mathrm{~N} \_\mathrm{H}\left(\mathrm{NH}_{3} *\right.$ to $\mathrm{NH}_{3}$ gas $) \mathrm{G}=-0.26$ and $\mathrm{G} \dagger=1.12$

5. $=>2 \mathrm{~N} \_\mathrm{NH}\left(\mathrm{H}^{*}+\mathrm{N}^{*} \rightarrow \mathrm{NH}^{*}\right) \mathrm{G}=0.22$ and $\mathrm{G} \dagger=0.66$

6. $=>2 \mathrm{~N} \_\mathrm{NH} \_2 \mathrm{H}\left(\mathrm{H}_{2}\right.$ gas $\left.\rightarrow \mathrm{H}^{*}+\mathrm{H}^{*}\right) \mathrm{G}=0.30$, we calculate a barrier of $0.57 \mathrm{eV}$.

7. $=>2 \mathrm{~N}_{-} \mathrm{NH}_{2} \_\mathrm{H}\left(\mathrm{NH}^{*}+\mathrm{H}^{*} \rightarrow \mathrm{NH}_{2}{ }^{*}\right) \mathrm{G}=-0.39$ and $\mathrm{G}^{\dagger}=0.56$, described in detail in transition state section.

8. $=>2 \mathrm{~N}_{-} \mathrm{NH}_{3}\left(\mathrm{NH}_{2} *+\mathrm{H}^{*} \rightarrow \mathrm{NH}_{3} *\right) \mathrm{G}=0.39$ and $\mathrm{G} \dagger=1.36$, however, there is an alternative path from $2 \mathrm{~N} \_\mathrm{NH}_{2} 2 \mathrm{H}$ to $2 \mathrm{~N}_{-} \mathrm{NH}_{3} \mathrm{H}$, with a lower barrier of $\mathrm{G} \dagger=1.13$, this will be further discusse $\overline{\text { in the }}$ kMC section. The resting state of this step is indeed $2 \mathrm{~N}_{-} \mathrm{NH}_{2} \mathrm{H}$, with $\mathrm{G}=$ 0.39 , together making this barrier $1.13+0.39=1.52$ in $\mathrm{kMC}$.

9. $\Rightarrow 2 \mathrm{~N}\left(\mathrm{NH}_{3}\right.$ *to $\mathrm{NH}_{3}$ gas) $\mathrm{G}=0.11$ and $\mathrm{G} \dagger=1.40$ Similar with the previous step, there is an alternative path from $2 \mathrm{~N}_{-} \mathrm{NH}_{3} \mathrm{H}=>2 \mathrm{~N} \_\mathrm{H}$, with a lower barrier of $\mathrm{G} \dagger=1.03$. Similarly, the resting state is $2 \mathrm{~N}_{-} \mathrm{NH}_{2}{ }_{-} \mathrm{H}$, with $\mathrm{G}=-0 . \overline{3}$, together making this barrier $0.39+1.03=1.42$ in $\mathrm{kMC}$. These alternative paths are shown in figure 2 using green color. 
10. $\Rightarrow>2 \mathrm{~N}_{-} \mathrm{N}_{2}\left(\mathrm{~N}_{2}\right.$ gas $\rightarrow \mathrm{N} 2 *$ triple bonded, top layer) $\mathrm{G}=0.20$. This step involves $\mathrm{N}_{2}$ adsorption $(\mathrm{G} \dagger=0.94)$ and its resting state is $2 \mathrm{~N} 2 \mathrm{H}$ (edge configuration, see the SI) with $\mathrm{G}=-0.63$, together making this barrier $0.94+0.63=1.57$ in $\mathrm{kMC}$.

11. $\Rightarrow>4 \mathrm{~N}\left(\mathrm{~N}_{2} * \rightarrow \mathrm{N}^{*}+\mathrm{N}^{*}\right) \mathrm{G}=-1.10$ and $\mathrm{G} \dagger=0.64$ is the highest barrier along $\mathrm{N}_{2}$ dissociation, see SI Fig. S4.

12. $=>3 \mathrm{~N} \_\mathrm{NH} \_\mathrm{H}\left(\mathrm{H}^{*}+\mathrm{N}^{*} \rightarrow \mathrm{NH}^{*}\right) \mathrm{G}=-0.65$ and $\mathrm{G} \dagger=-0.07$

13. $=>3 \mathrm{~N}_{-} \mathrm{NH}_{2}\left(\mathrm{NH}^{*}+\mathrm{H}^{*} \rightarrow \mathrm{NH}_{2} *\right.$ to complete the cycle $)$.

The above states are described by a simple linear energy landscape in Figure 2, confined in a $2 \times 2$ cell. However, we have also included the most populated states involved in the steady state $\mathrm{kMC}$ calculations, such as $2 \mathrm{~N} \_\mathrm{H}$ and $2 \mathrm{~N} \_2 \mathrm{H}$.

14. $3 \mathrm{~N} \__{-} \mathrm{NH}_{3}=>3 \mathrm{~N}\left(\mathrm{NH}_{3} *\right.$ to $\mathrm{NH}_{3}$ gas $), \mathrm{G}$ from $0.30=>0.41$, and $\mathrm{G} \dagger=1.34$

15. $2 \mathrm{~N}_{-} \mathrm{NH}_{2} \_2 \mathrm{H}=>2 \mathrm{~N}_{-} \mathrm{NH}_{3} \_\mathrm{H}\left(\mathrm{NH}_{2} *+\mathrm{H}^{*} \rightarrow \mathrm{NH}_{3} *\right), \mathrm{G}$ from $-0.27=>0.01$, and $\mathrm{G} \dagger=1.13$

16. $2 \mathrm{~N}_{-} \mathrm{NH}_{3} \mathrm{H}=>2 \mathrm{~N} \_\mathrm{H}\left(\mathrm{NH}_{3}\right.$ *to $\mathrm{NH}_{3}$ gas $), \mathrm{G}$ from $0.01 \Rightarrow-0.22$, and $\mathrm{G} \dagger=1.03$

17. $2 \mathrm{~N} \_\mathrm{H}=>2 \mathrm{~N}, \mathrm{G}$ from $-0.22=>0.11$

18. $2 \mathrm{~N}=>2 \mathrm{~N} \_2 \mathrm{H}, \mathrm{G}$ from $0.11=>-0.63$

In this simplified scheme we considered dissociative chemisorption of $\mathrm{H}_{2}$ gas to $\mathrm{H}^{*}+\mathrm{H}^{*}$ explicitly only for the step $2 \mathrm{~N}+\mathrm{H}_{2}$ gas to $2 \mathrm{~N} 2 \mathrm{H}$. This step is closest to the dissociative chemisorption of $\mathrm{N}_{2}$ gas to $\mathrm{N}^{*}+\mathrm{N}^{*}$ that in Section 5 we single out as the RDS in our kinetic model. We find that $\mathrm{NH}_{3}$ production rate changes from $17.7 \mathrm{sec}^{-1}$ per $2 \times 2$ site to TOF $17.5 \mathrm{sec}^{-1}$ if we use the calculated barrier of $0.57 \mathrm{eV}$ instead of setting the barrier to zero. For other steps we assume $\mathrm{H}_{2}$ dissociative chemisorption to have barrier that's small enough to not affect kinetics. And we form successive $\mathrm{NH}_{\mathrm{x}}$ species by the Langmuir-Hinshelwood (LH) mechanisms: $\mathrm{NH}_{\mathrm{x}}{ }^{*}+\mathrm{H}^{*} \rightarrow \mathrm{NH}_{\mathrm{x}+1}$ * (for PBE_D3, step $12 \mathrm{LH}$ is small enough, and not rate determining. Thus, we don't consider ER further).

The highest-energy transition states in the free energy landscape are, in decreasing order:

- TS3: step 3 with $\mathrm{G} \dagger=1.47 \mathrm{eV}$ involves $\mathrm{H}^{*}+\mathrm{NH}_{2} *=>\mathrm{NH}_{3} *$, an $\mathrm{LH}$ mechanism. The detailed transition state structure is shown in Fig S3(b) of the SI.

- TS 8: step 8 with $\mathrm{G}^{\dagger}=1.13 \mathrm{eV}$ involves $\mathrm{H}^{*}+\mathrm{NH}_{2} *=>\mathrm{NH}_{3}{ }^{*}$, an $\mathrm{LH}$ mechanism. The detailed transition state structure is shown in Fig S3(a) of the SI.

- TS4: step 4 with $\mathrm{G}^{\dagger}=1.12 \mathrm{eV}$ involves $\mathrm{NH}_{3}{ }^{*}=>\mathrm{NH}_{3}$ gas, just as in step 9. We used electronic adsorption energy of $\mathrm{NH} 3$ with ZPE correction as the desorption barrier.

- TS9: step 9 with $\mathrm{G} \uparrow=1.03 \mathrm{eV}$ involves $\mathrm{NH}_{3}{ }^{*}=>\mathrm{NH}_{3}$ gas, shown in the green path of figure 2 . Here, we considered the alternative pathway of desorption $\mathrm{NH}_{3}$ from $2 \mathrm{~N}_{-} \mathrm{NH}_{3} \mathrm{H}$. We used electronic adsorption energy of $\mathrm{NH}_{3}$ with $\mathrm{ZPE}$ correction as the desorption barrier.

- TS10: step 10 with $\mathrm{G}^{\dagger}=0.94 \mathrm{eV}$, we included $\mathrm{N}_{2}$ adsorption into consideration, and used the electronic adsorption energy together with ZPE as the desorption barrier, and this leads to $\mathrm{G}^{\dagger}=0.94 \mathrm{eV}$.

- $\quad$ TS5: step 5 with $\mathrm{G} \dagger=0.66 \mathrm{eV}$ involves $\mathrm{H}^{*}+\mathrm{N}^{*}=>\mathrm{NH}^{*}$, an $\mathrm{LH}$ mechanism. The NEB energy and structures are shown in Fig. S2(a) of the SI. This is the lowest energy barrier for adding an $\mathrm{H}$ to $\mathrm{NHx}$. We also examined $3 \mathrm{~N} \_\mathrm{H}+\mathrm{H}_{2}$ (gas) $=>2 \mathrm{~N} \_\mathrm{NH} \_2 \mathrm{H}$ in which gas phase 
$\mathrm{H}_{2}$ adds to $\mathrm{N}^{*}$ to form $\mathrm{NH}^{*}+\mathrm{H}^{*}$, This involves a high energy intermediate state with $\mathrm{G}=$ $1.78 \mathrm{eV}$, so we will not consider this step further.

- TS 11: step 11 with $\mathrm{G}+=0.64 \mathrm{eV}$. We took consideration of $\mathrm{N}_{2}$ dissociation.

a) the initial bonding of $\mathrm{N}_{2}$ retains the triple-bond while making a sigma bond to an on-top site on the first layer (denoted $\sigma \mathrm{N} \equiv \mathrm{N}-\mathrm{T}$ phase, where $\equiv$ in the middle represents the bond order, and T represents adsorption on top layer, or Nørskov $\gamma$ )

b) there is a barrier to moving to a sigma bond to an on-top site on the second layer (denoted $\sigma \mathrm{N} \equiv \mathrm{N}-\mathrm{S}$, where $\mathrm{S}$ represents adsorption on second layer, or Nørskov $\delta$ )

c) There is a barrier for one $\pi$ bond of $\mathrm{N}_{2}$ to bind to two surface Fe atoms (denoted as $\pi \mathrm{N}=\mathrm{N}-\eta_{2}$ or Nørskov $\alpha$ )

d) There is a barrier for the $2^{\text {nd }} \pi$ bond of $\mathrm{N}_{2}$ to $4 \mathrm{~N}$, with the N-N bonding to three surface Fe atoms (denoted as $2 \pi \mathrm{N}-\mathrm{N} \eta_{3}$ or Nørskov $\alpha^{\prime}$ )

e) Finally, there is a barrier for the remaining $\mathrm{N}-\mathrm{N}$ bond to dissociate with each $\mathrm{N}$ bonding to 4 surface atoms (denoted as Nørskov $\beta$ phase), leading to the $4 \mathrm{~N}$ state. The NEB energy and structures for $\mathrm{N}_{2}$ dissociation are shown in Fig. S4 of the SI.

- TS7: step 7 with $\mathrm{G}_{\dagger}^{\dagger}=0.56 \mathrm{eV}$ involves $\mathrm{H}^{*}+\mathrm{NH}^{*} \rightarrow \mathrm{NH}_{2}{ }^{*}$, an $\mathrm{LH}$ mechanism. The NEB energy and structures are shown in Fig. S2(b) of the SI.

- TS12: step 12 with $\mathrm{G}^{\dagger}=-0.07 \mathrm{eV}$ is an $\mathrm{LH}$ mechanism in which $\mathrm{H}^{*}+\mathrm{N}^{*}=>\mathrm{NH}^{*}$

- State 13. This is the same as the state 1 but the $\mathrm{G}=-1.22 \mathrm{eV}$ because we have produced two $\mathrm{NH}_{3}$ from $3 \mathrm{H}_{2}+\mathrm{N}_{2}$. Similarly, state 11 has $\mathrm{G}=-1.10$ because we already have produced two $\mathrm{NH}_{3}$ along the pathway.

The energy landscape is plotted in Figure 2 for the Somorjai experimental conditions of $673^{\circ} \mathrm{K}$ and $20 \mathrm{~atm}$ of total pressure $\left(\mathrm{H}_{2} \text { and } \mathrm{N}_{2} \text { in stoichiometric ratio and } \mathrm{NH}_{3} \text { pressure }=1.5 \text { torr }\right)^{13}$. The lowest free energy state $3 \mathrm{~N}_{-} \mathrm{NH}_{2}$ is taken as reference, setting $\mathrm{G}=0$.

\section{PBE_D3, 673K, 20 atm}

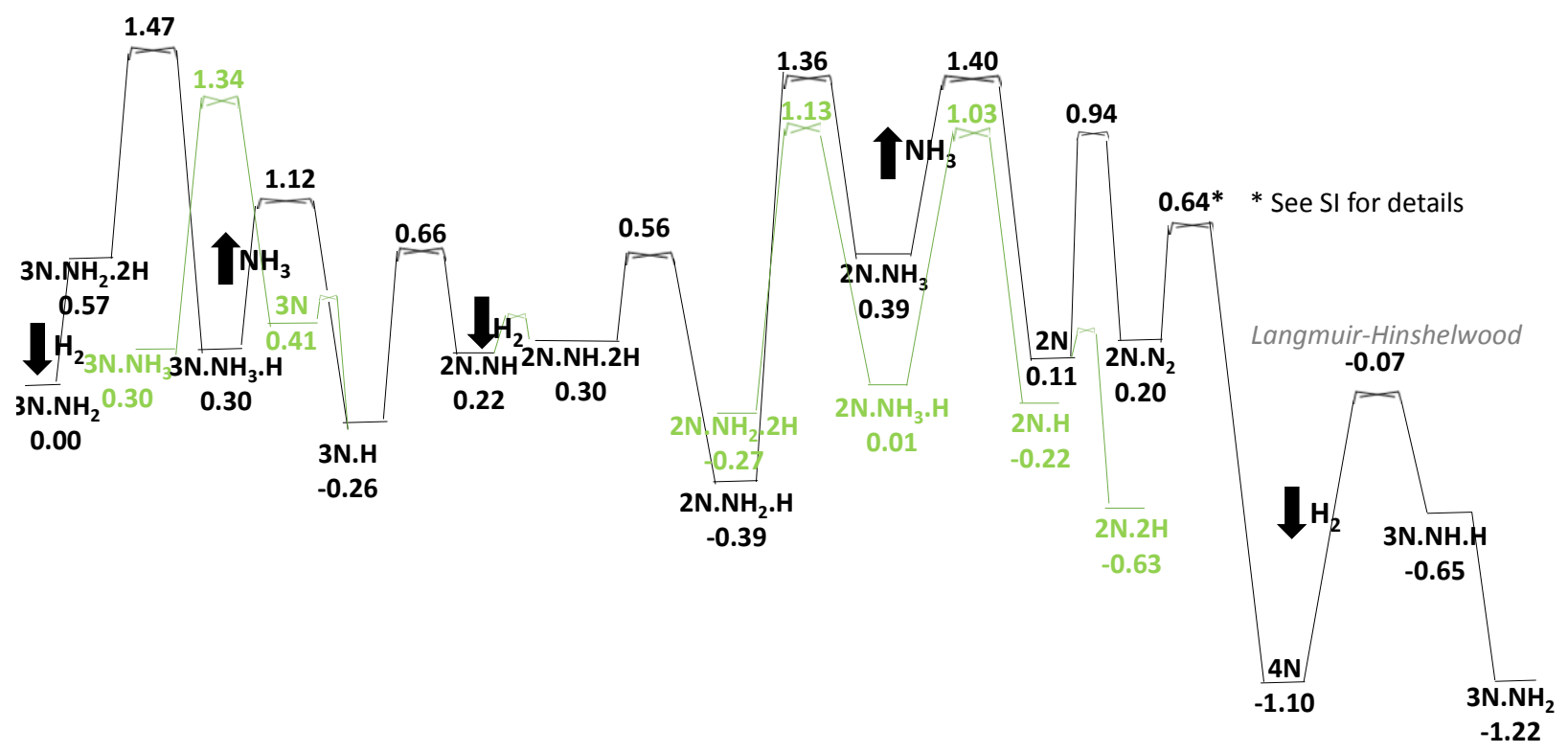


Figure 2. Energy landscape for $\mathrm{NH}_{3}$ synthesis reactions under Somorjai condition, $673^{\circ} \mathrm{K}$, 20atm. The lowest energy state $3 \mathrm{~N} \mathrm{NH}_{2}$ is taken as reference, with a free energy of zero. We considered the linear pathway in black and proposed alternative pathway in green, in order to obtain the optimum barriers.

$\mathrm{NH}_{3}$ production rate is dominated by 3 steps:

1). $\mathrm{N}_{2}$ dissociation and desorption,

2). hydrogenation of $\mathrm{NH}_{2}$, and

3). $\mathrm{NH}_{3}$ desorption.

This diagram considers the reaction of $3 \mathrm{H}_{2}$ plus $1 \mathrm{~N}_{2}$ to form $2 \mathrm{NH}_{3}$, so that the total free energy decreases by $1.22 \mathrm{eV}$ as we go from $3 \mathrm{~N}_{-} \mathrm{NH}_{2}$ on the left to $3 \mathrm{~N}_{-} \mathrm{NH}_{2}$ on the right. The free energy diagram with same states calculated at PBE level can be found in SI fig. S1.

The simplified reaction pathway described above is illustrated pictorially in Figure 3 showing the surface structure step by step, to clarify the nature of each adsorption site and the interactions between these adsorbed species.

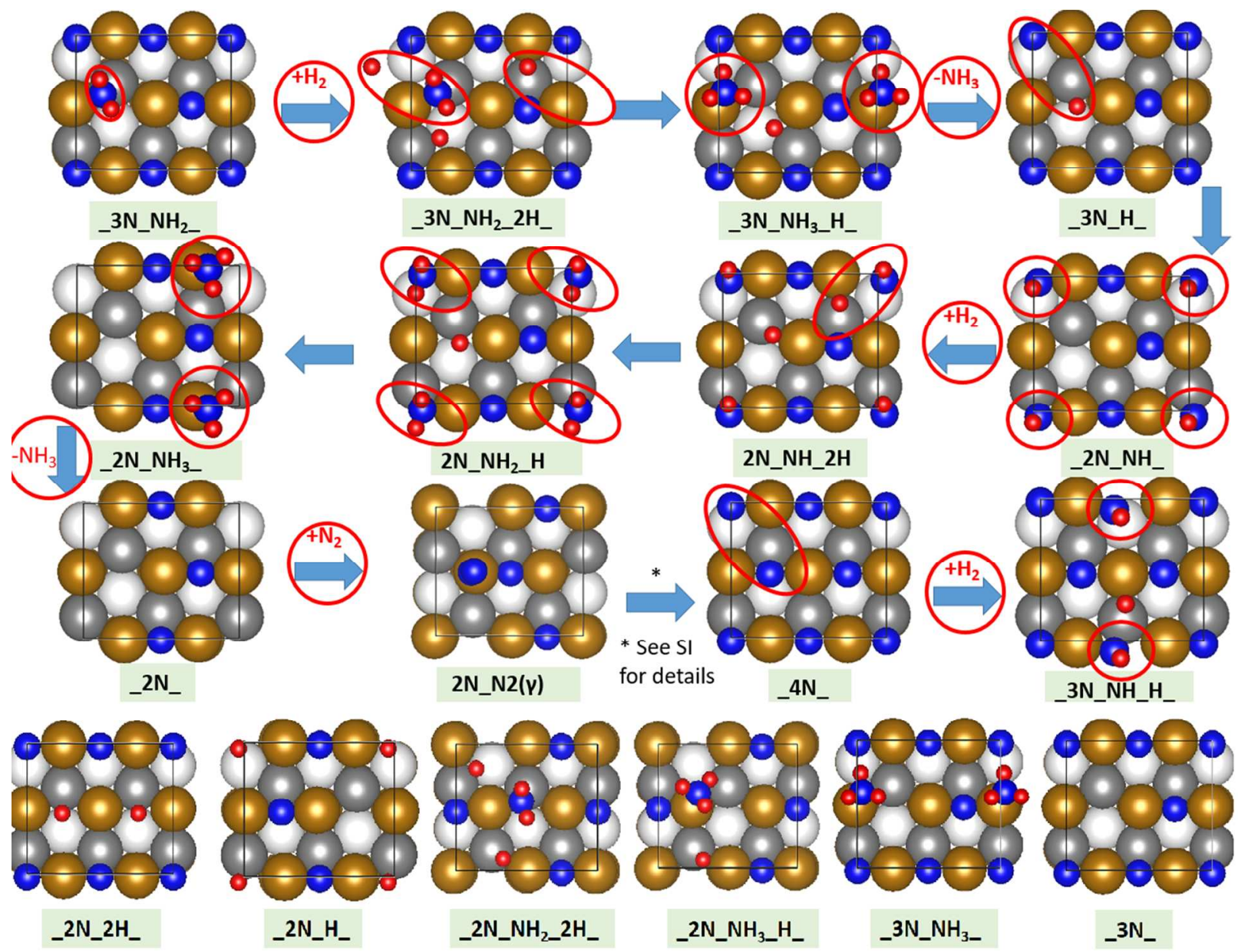

Figure 3. Surface structure for selected reaction steps in Fig. 2. Bronze spheres represent first layer Fe atoms, Dark gray represents second layer Fe atoms, and white represents third layer Fe 
atoms. Nitrogen atoms are shown using navy blue spheres, and hydrogen atoms are shown using red spheres. Every intermediate structure is geometrically optimized with the results summarized in Fig (3) to illustrate the adsorption sites for various species, and interaction between these adsorbed species. Note that in cases where species are at the edges, we show all images that map onto the $2 \times 2$ cell. In cases where a circle is used to highlight the reactive species at an edge we show the other equivalent circles.

Transition state geometries are shown in SI Fig. S2-4. We considered five reactions:

A. 3N_H $=>2 \mathrm{~N} \_\mathrm{NH}$, migration of hydrogen and addition to $\mathrm{N}$ on the surface (LH);

B. 2N_NH_2H $=>2 \mathrm{~N}_{-} \mathrm{NH}_{2} \_\mathrm{H}$, hydrogen migration and addition to $\mathrm{NH}$ on the surface (LH);

C. $3 \mathrm{~N}_{-} \mathrm{NH}_{2}{ }_{2} 2 \mathrm{H}=>3 \mathrm{~N}_{-} \mathrm{NH}_{3} \mathrm{H}$, hydrogen migration and addition to $\mathrm{NH}_{2}$ on the surface (LH);

D. $2 \mathrm{~N}_{-} \mathrm{NH}_{2}{ }_{2} \mathrm{H}=>2 \mathrm{~N}_{-} \mathrm{NH}_{3} \mathrm{H}$, hydrogen migration and addition to $\mathrm{NH}_{2}$ on the surface (LH);

E. $2 \mathrm{~N}_{-} \mathrm{N}_{2}=>4 \mathrm{~N}$. This involves a complex pathway from triple-bonded $\mathrm{N}_{2}$ adsorbed on first layer $(\sigma \mathrm{N} \equiv \mathrm{N}-\mathrm{T}$ or $\gamma)=>$ triple-bonded $\mathrm{N}_{2}$ adsorbed on second layer $(\sigma \mathrm{N} \equiv \mathrm{N}-\mathrm{S}$ or $\delta) \Rightarrow$ double-bonded $\mathrm{N}_{2}$ to a bridge site $\left(\pi \mathrm{N}=\mathrm{N}_{2}\right.$ or $\left.\alpha\right) \Rightarrow>$ single-bonded $\mathrm{N}_{2}$ at a 3 -fold site $(2 \pi \mathrm{N}-$ $\mathrm{N}_{3}$ or $\left.\alpha^{\prime}\right)=>$ the dissociated state $4 \mathrm{~N}(\beta)$.

\section{Discussion of the wavefunctions}

Since $\mathrm{Fe}$ is ferromagnetic, we analyzed the magnetic moments of the various atoms and the changes in the key steps of ammonia synthesis. Total magnetic moments for all the states along the pathway can be found in Table 1 .

\begin{tabular}{|c|c|c|c|c|c|c|}
\hline name & $\begin{array}{c}\text { total } \\
\operatorname{mag}(\mathrm{uB})\end{array}$ & dMAG & $\begin{array}{c}\text { covalent } \\
\text { bond to } \\
\mathrm{Fe}\end{array}$ & ratio & \#comment & \#comment \\
\hline 111_surface_24Fe & 64.76 & 0.00 & 0 & & & 2.70 per $\mathrm{Fe}$ \\
\hline $3 \mathrm{~N} . \mathrm{NH}_{2}$ & 57.10 & -7.66 & 10 & $77 \%$ & $3 * 3+1$ & \\
\hline $3 \mathrm{~N} . \mathrm{NH}_{2} .2 \mathrm{H}$ & 56.49 & -8.26 & 12 & $69 \%$ & $3 * 3+1+2$ & 0.3 per $\mathrm{H}$ \\
\hline TS_3N.NH $2.2 \mathrm{H}$ & 55.94 & -8.82 & & & & \\
\hline $3 \mathrm{~N} \cdot \mathrm{NH}_{3} \cdot \mathrm{H}$ & 56.33 & -8.43 & 10 & $84 \%$ & $3 * 3+1$ & \\
\hline $3 \mathrm{~N} . \mathrm{H}+\mathrm{NH}_{3}(\mathrm{~g})$ & 57.00 & -7.75 & 10 & $78 \%$ & $3 * 3+1$ & \\
\hline TS_3N.H+NH 3 (g) & 57.54 & -7.22 & & & & \\
\hline $2 \mathrm{~N} . \mathrm{NH}+\mathrm{NH}_{3}(\mathrm{~g})$ & 58.17 & -6.59 & 8 & $82 \%$ & $3 * 2+2$ & \\
\hline $2 \mathrm{~N} . \mathrm{NH} .2 \mathrm{H}+\mathrm{NH}_{3}(\mathrm{~g})$ & 57.27 & -7.48 & 10 & $75 \%$ & $3 * 2+2+2$ & \\
\hline TS_2N.2H.NH+NH ${ }_{3}(\mathrm{~g})$ & 58.80 & -5.96 & & & & \\
\hline 2N.NH2.H+NH $(\mathrm{g})$ & 59.35 & -5.40 & 8 & $68 \%$ & $3 * 2+1+1$ & \\
\hline TS_2N.H.NH2+NH ${ }_{3}(\mathrm{~g})$ & 59.08 & -5.67 & & & & \\
\hline $2 \mathrm{~N}^{2} \mathrm{NH}_{3}+\mathrm{NH}_{3}(\mathrm{~g})$ & 59.45 & -5.30 & 6 & $88 \%$ & $3 * 2$ & \\
\hline $2 \mathrm{~N}$ _diagonal. $\mathrm{NH}_{2} \cdot 2 \mathrm{H}$ & 58.32 & -6.44 & 9 & $72 \%$ & $2 * 3+1+2$ & \\
\hline TS_2N_diagonal. $\mathrm{NH}_{2} \cdot 2 \mathrm{H}$ & 58.64 & -6.12 & & & & \\
\hline $2 \mathrm{~N} \_$diagonal. $\mathrm{NH}_{3} \cdot \mathrm{H}$ & 59.08 & -5.68 & 7 & $81 \%$ & $2 * 3+1$ & 2.84 per $\mathrm{N}$ \\
\hline $2 \mathrm{~N}+2 \mathrm{NH}_{3}(\mathrm{~g})$ & 59.83 & -4.93 & 6 & $82 \%$ & $3 * 2$ & \\
\hline $2 \mathrm{~N} . \mathrm{N} 2(\sigma \mathrm{N} \equiv \mathrm{N}-\mathrm{T})+2 \mathrm{NH}_{3}(\mathrm{~g})$ & 58.83 & -5.92 & 6 & $99 \%$ & $3 * 2$ & No N2 to Fe \\
\hline $\mathrm{TS}(\sigma \mathrm{N} \equiv \mathrm{N}-\mathrm{T}=>\sigma \mathrm{N} \equiv \mathrm{N}-\mathrm{S})$ & 59.21 & -5.54 & & & & \\
\hline
\end{tabular}




\begin{tabular}{|c|c|c|c|c|c|c|}
\hline $2 \mathrm{~N} . \mathrm{N} 2(\sigma \mathrm{N} \equiv \mathrm{N}-\mathrm{S})+2 \mathrm{NH}_{3}(\mathrm{~g})$ & 58.51 & -5.54 & 6 & $92 \%$ & $3 * 2$ & No N2 to Fe \\
\hline $\mathrm{TS}(\sigma \mathrm{N} \equiv \mathrm{N}-\mathrm{S}=>\pi \mathrm{N}=\mathrm{N})$ & 58.37 & -6.38 & & & & \\
\hline $2 \mathrm{~N} . \mathrm{N} 2(\pi \mathrm{N}=\mathrm{N})+2 \mathrm{NH}_{3}(\mathrm{~g})$ & 58.65 & -6.11 & 8 & $76 \%$ & $3 * 2+2$ & 2 new N-Fe \\
\hline $\mathrm{TS}(\pi \mathrm{N}=\mathrm{N}=>2 \pi \mathrm{N}-\mathrm{N})$ & 58.53 & -6.23 & & & & \\
\hline $2 \mathrm{~N} \_\mathrm{N} 2(2 \pi \mathrm{N}-\mathrm{N})+2 \mathrm{NH}_{3}(\mathrm{~g})$ & 58.17 & -6.59 & 10 & $66 \%$ & $3 * 2+4$ & 4 new N-Fe \\
\hline $\mathrm{TS}(2 \pi \mathrm{N}-\mathrm{N}=>\mathrm{N}+\mathrm{N})$ & 57.36 & -7.39 & & & 8 & \\
\hline $4 \mathrm{~N}+2 \mathrm{NH}_{3}(\mathrm{~g})$ & 54.77 & -9.98 & 12 & $83 \%$ & $3 * 4$ & 2.50 per N \\
\hline $4 \mathrm{~N} .2 \mathrm{H}+2 \mathrm{NH}_{3}(\mathrm{~g})$ & 54.32 & -10.44 & 14 & $75 \%$ & $3 * 4+2$ & \\
\hline $\mathrm{TS} \_4 \mathrm{~N}_{2} \mathrm{H}_{2}$ & 55.40 & -9.35 & & & & \\
\hline 3N.NH.H+2 $\mathrm{NH}_{3}(\mathrm{~g})$ & 55.92 & -8.84 & 12 & $74 \%$ & $3 * 3+2+1$ & \\
\hline 3N.NH${ }_{2}+2 \mathrm{NH}_{3}(\mathrm{~g})$ & 57.10 & -7.66 & 10 & $77 \%$ & $3 * 3+1$ & \\
\hline $\begin{array}{c}\text { Average in covalent } \\
\text { character }\end{array}$ & & & & $77 \%$ & & \\
\hline
\end{tabular}

Table 1. Analysis of change in spin along the pathway. Total magnetic moment for each state and the change with respect to pure Fe are reported. Covalent bond calculated using simple VB theory is presented in covalent bond column, and we assume each adsorbed $\mathrm{N}, \mathrm{NH}, \mathrm{NH}_{2}, \mathrm{NH}_{3}, \mathrm{H}$ to decrease spin moment $3,2,1,0,1$ respectively.

We observe non-negligible changes in these moments along the reaction pathways.

In earlier studies of hydrocarbon intermediates on the metals $\mathrm{Ru}, \mathrm{Rh}, \mathrm{Pd}, \mathrm{Os}, \mathrm{Ir}, \mathrm{Pt}$, Kua and Goddard proposed a Valence Bond (VB) model in which alkyl, alkylidene, and alkylidyne intermediates to a metal surface are considered to make 1, 2, or 3 valence bonds to the metal surface and showed that this correlates well with bond energies and other properties. ${ }^{42-45} \mathrm{We}$ propose a similar valence bond (VB) model to understand the spin changes in spin for Fig. 4(a) and SI table 2. We assume that each of the unpaired spins of $\mathrm{N}$ atom makes a covalent bond to an unpaired spin on the neighboring Fe atoms, reducing the spin by 3 units. Indeed, for the $4 \mathrm{~N}$ state the spin of the cluster is reduced by 10.51 or 2.63 spins per N. We will also assume that the two unpaired spins of $\mathrm{NH}$ can make two bonds, which should reduce the Fe spin by 2 units and $\mathrm{NH}_{2}$ can make one =bonds, which should reduce it by 1 unit as should $\mathrm{H}$.

From table 1, we see that the net spin changes observed in the 14 states that are not TS, average $77 \%$ of the expected value for this model, supporting this simple Valence Bond view of bonding. Of course a more complete analysis should consider the ligand field splitting to these unpaired spins and the orbital requirements to form a covalent bond from the Fe d-orbitals to the $\mathrm{N} \mathrm{p}$ orbitals, but we think that the simple VB view accounts for the major spin coupling effects.

These changes in magnetic moment suggests an important role for spin in the reactions, which suggests that engineering the spin of surface atom may provide a new way to increase Haber Bosch reaction efficiency. This suggests designing new catalysts that have different spin character, e.g., $\mathrm{Co}, \mathrm{Ni}, \mathrm{Mn}$, or $\mathrm{Cr}$ all of which can exhibit localized spins, or $\mathrm{Ru}$ or Os which should not have large spins. Also the changes in the oxidation state of the atoms reported in Figure 4(b) are noteworthy and analogously suggest an important concomitant effect of charge transfer effects.

\section{Kinetic modelling results with illustrations for $\mathrm{T}=673^{\circ} \mathrm{K}$ and $\mathrm{p}=20 \mathrm{~atm}$}

\section{5a. Kinetic Monte Carlo Simulations}


The free energies in Fig. 2 provide a crude estimate for the rate. Here we might estimate the rate from transition state theory (TST) as $\mathrm{k}=\left(\mathrm{k}_{\mathrm{B}} \mathrm{T} / \mathrm{h}\right) \exp \left[-1.57 / \mathrm{k}_{\mathrm{B}} \mathrm{T}\right]=24 \mathrm{sec}^{-1}$, leading (after multiplication by a factor of 2 due to the presence of 2 reaction sites in the unit cell) to a TOF of $48 \mathrm{NH}_{3}$ molecules per second per $(2 \times 2)$ unit cell.

However, for such a complex mechanism, it is necessary to go beyond this rough estimate with simulations that include all distributions of the states involved and the rates between them in a full $\mathrm{kMC}$ model, allowing the system to achieve steady state. We evaluated each rate using transition state theory as $\left(\mathrm{k}_{\mathrm{B}} \mathrm{T} / \mathrm{h}\right) \exp \left(-\Delta \mathrm{G} \dagger / \mathrm{k}_{\mathrm{B}} \mathrm{T}\right)$, where $\Delta \mathrm{G} \dagger$ is the difference in free energy between the starting state and the saddle point. In the case of ER reactions involving gas-phase species turning into adsorbates, we again use transition state theory, but for the reverse LH process, and then we invoke microscopic reversibility principle to calculate the rate of the direct process.

This system is not in equilibrium. To consider the kinetics of the system in steady state, we carried out kMC calculations as discussed below. In this case we find that the state $2 \mathrm{~N} \_2 \mathrm{H}$ has the lowest $\Delta \mathrm{G}$ under steady-state conditions at $\mathrm{P}\left(\mathrm{H}_{2}\right)=15$ atm, $\mathrm{P}\left(\mathrm{N}_{2}\right)=5$ atm, $\mathrm{P}\left(\mathrm{NH}_{3}\right)=1.5$ torr, $\mathrm{T}$ $=673{ }^{\circ} \mathrm{K}$, and the free-energy difference between this state and the highest point $\Delta \mathrm{G} \dagger$ along the reaction path is $1.57 \mathrm{eV}$. Taking into consideration the states important in the $\mathrm{kMC}$ calculations and varying $\mathrm{NH}_{3}$ pressure leads to the diagram in Figure 4.

\section{PBE_D3 Effect of NH3 Pressure}

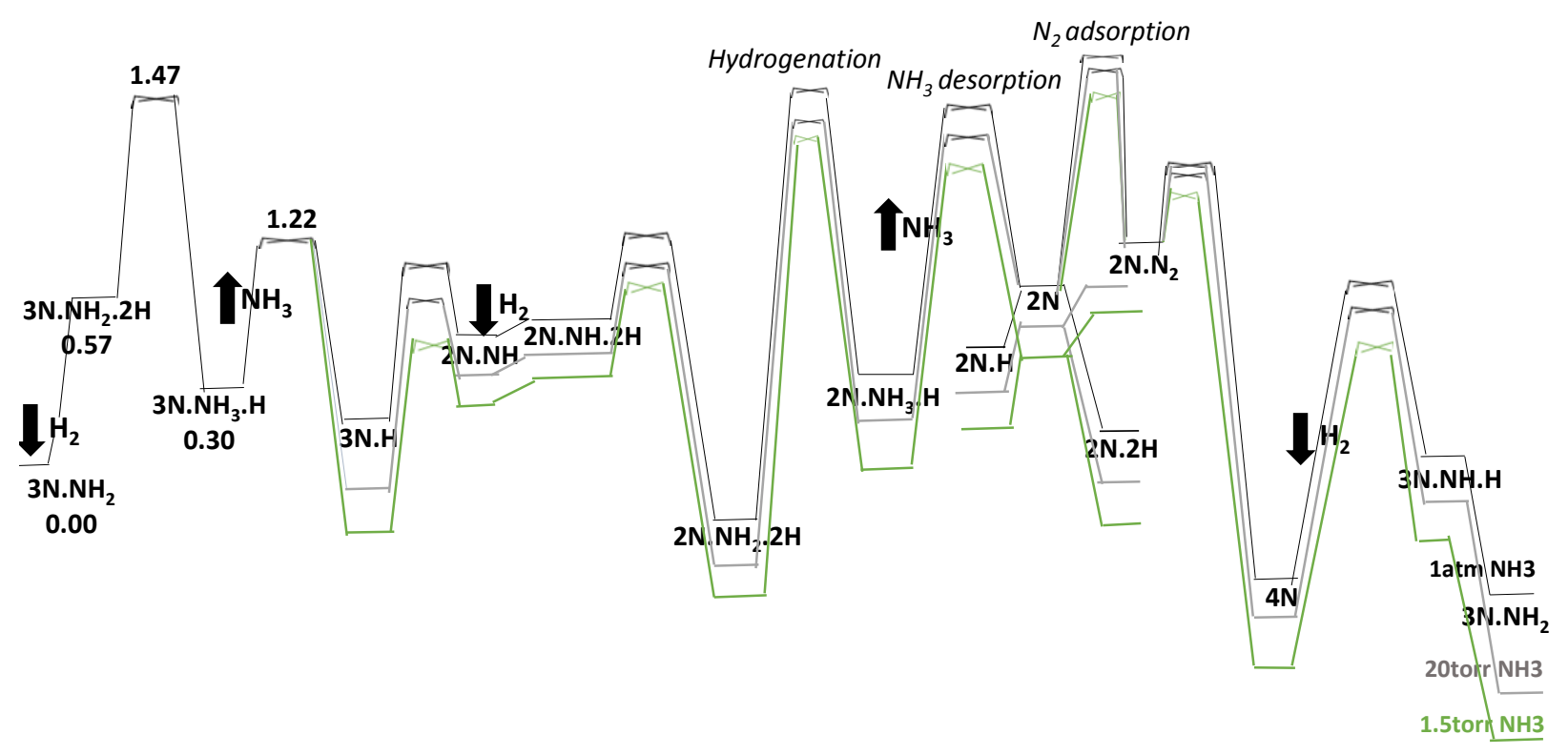

Figure 4. Illustration of how the equilibrium energy landscape from Figure 2 becomes modified for steady state kinetics of forming $\mathrm{NH}_{3}$ at different pressures from 15 atm of $\mathrm{H}_{2}$ and 5 atm of $\mathrm{N}_{2}$ at $673^{\circ} \mathrm{K}$ (Somorjai conditions). We show the results for three pressures of $\mathrm{NH}_{3}$ product: 1.5 torr, 20 torr, and $1 \mathrm{~atm}$. Barriers in green are assumed to be fast and assigned rates of $10^{11} \mathrm{~s}^{-1}$. The populations are shown in Table 2 . We see here that $\mathrm{NH}_{3}$ acts as a poison, decreasing the TOF from 17.7 at 1.5 torr, to 16.5 at 20 torr, to 2.8 at 1 atm. 
In the Somorjai et $\mathrm{al}^{13}$ papers, the measured ammonia production at $673{ }^{\circ} \mathrm{K}$ and $15 \mathrm{~atm} \mathrm{H}_{2}, 5 \mathrm{~atm}$ $\mathrm{N}_{2}$, extrapolated to zero ammonia pressure is $2.8 \times 10^{9} \mathrm{NH}_{3} \mathrm{moles} / \mathrm{cm}^{2} / \mathrm{sec}$ which corresponds to 9.7 $\mathrm{NH}_{3}$ molecules produced per second on a $(2 \times 2)$ unit cell.

We conducted $\mathrm{kMC}$ simulations at $\mathrm{T}=673{ }^{\circ} \mathrm{K}$ and pressures: $\mathrm{pH}_{2}=15 \mathrm{~atm}, \mathrm{pN}_{2}=5$ atm and $\mathrm{pNH}_{3}=$ 1.5 torr. We used 20 independent replicas and $2 \times 10^{9} \mathrm{kMC}$ steps each (checking that the results converged within $5 \%$ with respect to a test case using 100 replicas and $2 \times 10^{10} \mathrm{kMC}$ steps) for a total simulated time of $2733 \mathrm{sec}$. This leads to production of $48482 \mathrm{NH}_{3}$ molecules produced by our $(2 \times 2)$ unit cell, corresponding to a predicted $\mathrm{TOF}=17.7 \mathbf{N H}_{3}$ molecules per second per (2x2) site, in good agreement with the experimentally measured TOF of 9.7 (our predicted rate should be higher than experiment since our surface is perfect). We should caution here that the final TOF is very sensitive to the key barriers at the RDS. Thus to change the 17.7 to 9.7 we need only increase the free energy of the transition state for the 10 th step from $0.94 \mathrm{eV}$ to 0.98 $\mathrm{eV}$.

As shown in the SI, exactly the same set of calculations at the PBE level without D3 find TOF=89.3 compared to 17.7 for PBE-D3 and 9.7 experiment. This indicates that for this system PBE-D3 provides better accuracy than pure PBE. However, the rate for the PBE level would match experiment by changing the barrier for the 3rd step from $1.47 \mathrm{eV}$ to $1.64 \mathrm{eV}$. Of course the real accuracy depends on that for quite a number of individual steps.

The steady-state apparent $\Delta \mathrm{G}$ (i.e., the logarithm of the relative populations) for the most important states are reported in Table 2, which shows that the processes before and after the ammonia desorption are not far from equilibrium. That is, the populations are not far from those expected on the basis of their equilibrium $\Delta \mathrm{G}$ according to the Boltzmann distribution (the percent of residence times is also shown), except for the irreversible ammonia desorption steps.

If instead of $\mathrm{NH}_{3}=1.5$ torr, we use $\mathrm{NH}_{3}=1$ atm, shown in Figure 5, the total rate from the $\mathrm{kMC}$ is $2.8 \mathrm{NH}_{3}$ molecules per second per $(2 \times 2)$ site. Thus $\mathrm{NH}_{3}$ is a poison. Somorjai et al does not report the dependence of TOF on $\mathrm{NH}_{3}$ pressure for the (111), but they do report it for $\mathrm{Fe}(100)^{14}$ :

- for 20 torr pressure of $\mathrm{NH}_{3}, \mathrm{TOF}=0.21 \mathrm{NH}_{3}$-molecules $/ \mathrm{sec} /(2 \times 2)$

- for 1.5 torr pressure of $\mathrm{NH}_{3}, \mathrm{TOF}=1.1 \mathrm{NH}_{3}-$ molecules/sec/(2x2)

- extrapolating to zero $\mathrm{NH}_{3}$ pressure, leads to $\mathrm{TOF}=1.5 \mathrm{NH}_{3}$-molecules/sec/(2x2).

Thus the experimental poisoning effect of $\mathrm{NH}_{3}$ on (100) is similar to what we predict for (111).

Analogous $\mathrm{kMC}$ simulations at $\mathrm{T}=730^{\circ} \mathrm{K}$ and pressures: $\mathrm{pH}_{2}=15 \mathrm{~atm}, \mathrm{pN}_{2}=5$ atm and $\mathrm{pNH}_{3}=1.5$ torr give a TOF $=83.3 \mathrm{NH}_{3}$ molecules per second per $(2 \times 2)$ site which is still in reasonable agreement with the experimentally measured TOF of 22.8 from Figure 13 of Ref. ${ }^{13}$ In conclusion, we find that hydrogenation of $\mathrm{NH}_{2}, \mathrm{NH}_{3}$ desorption, $\mathrm{H}_{2}$ poisoning, and $\mathrm{N}_{2}$ desorption can be rate determining depending on the reaction conditions, while previous work on Fe-catalysts emphasized on $\mathrm{N}_{2}$ dissociation being the sole rate determining step. ${ }^{12}$

\section{5b. Rates for typical Haber Bosch conditions: $T=7^{\circ} 3^{\circ} \mathrm{K}$ and $\mathrm{p}=200 \mathrm{~atm}$}

The Haber-Bosch (HB) industrial process is conducted under a range of temperatures and pressures, with typical temperatures in the range $450-550{ }^{\circ} \mathrm{C}$ and total pressure around $\sim 200 \mathrm{~atm}$ with a stoichiometric ratio of $\mathrm{N}_{2}$ and $\mathrm{H}_{2}$. To compare our predictions with industrial conditions, 
we choose $\mathrm{T}=730{ }^{\circ} \mathrm{K}$ and two sets of pressures: $\left(\mathrm{pH}_{2}=150 \mathrm{~atm}, \mathrm{pN}_{2}=50\right.$ atm, $\left.\mathrm{pNH}_{3}=1 \mathrm{~atm}\right)$, and $\left(\mathrm{pH}_{2}=120 \mathrm{~atm}, \mathrm{pN}_{2}=40 \mathrm{~atm}, \mathrm{pNH}_{3}=20 \mathrm{~atm}\right)$, corresponding approximately to conditions holding at the beginning and the end of the HB process. For comparison, we also add that at $\mathrm{pNH}_{3}=1.5$ torr Figure 2 becomes Figure S6 of the SI leading to a naïve TOF= 258 (or 516 after multiplying by a factor of 2), which is about 5 times what we predict for Somorjai conditions using the same rough formula.

Running kMC simulations under these two conditions leads to $\mathrm{NH}_{3}$ production rates of 93.7 $\mathrm{NH}_{3}$-molecules/sec/(2x2) at $\mathrm{pNH}_{3}=1 \mathrm{~atm}$, and $18.5 \mathrm{NH}_{3}$-molecules/sec/(2x2) at $\mathrm{pNH}_{3}=20$ atm, respectively. Free energy differences due to populations and thermodynamic free energy differences for various states are shown in Table 2.

\begin{tabular}{|c|c|c|c|c|c|c|c|c|c|}
\hline \multirow[b]{2}{*}{ configuration } & \multicolumn{3}{|c|}{$\begin{array}{l}\mathrm{T}=673, \mathrm{pH}_{2}=15, \mathrm{pN}_{2}=5, \\
\mathrm{pNH}_{3}=1.5 / 760\end{array}$} & \multicolumn{3}{|c|}{$\begin{array}{l}\mathrm{T}=730, \mathrm{pH}_{2}=150, \mathrm{pN}_{2}=50 \\
\mathrm{pNH}_{3}=1\end{array}$} & \multicolumn{3}{|c|}{$\begin{array}{l}\mathrm{T}=730, \mathrm{pH}_{2}=120, \mathrm{pN}_{2}=40 \\
\mathrm{pNH}_{3}=20\end{array}$} \\
\hline & $t_{i}(\%)$ & $-\ln \left(\mathrm{P}_{\mathrm{i}} / \mathrm{P}_{0}\right)$ & $\Delta \mathrm{G}$ & $t_{i}(\%)$ & $-\ln \left(\mathrm{P}_{\mathrm{i}} / \mathrm{P}_{0}\right)$ & $\Delta \mathrm{G}$ & $t_{i}(\%)$ & $-\ln \left(\mathrm{P}_{\mathrm{i}} / \mathrm{P}_{0}\right)$ & $\Delta \mathrm{G}$ \\
\hline $3 \mathrm{~N} \mathrm{NH}_{2}$ & 6.5 & 0.00 & 0.00 & 1.4 & 0.00 & 0.00 & 7.2 & 0.00 & 0.00 \\
\hline $3 \mathrm{~N} \_\mathrm{NH}_{2}-2 \mathrm{H}$ & $3 \mathrm{E}-4$ & 0.57 & 0.57 & $5 \mathrm{E}-4$ & 0.50 & 0.49 & $2 \mathrm{E}-3$ & 0.51 & 0.51 \\
\hline $3 \mathrm{~N} \mathrm{NH}_{3} \mathrm{H}$ & $6 \mathrm{E}-4$ & 0.54 & 0.30 & 0.003 & 0.38 & 0.21 & 0.19 & 0.23 & 0.23 \\
\hline $3 \mathrm{NH}$ & 1.1 & 0.10 & -0.26 & 0.32 & 0.09 & -0.08 & 1.2 & 0.11 & 0.11 \\
\hline $2 \mathrm{~N} \mathrm{NH}$ & $6 \mathrm{E}-4$ & 0.54 & 0.22 & $3 \mathrm{E}-4$ & 0.52 & 0.39 & $1 \mathrm{E}-3$ & 0.54 & 0.59 \\
\hline $2 \mathrm{~N} \_\mathrm{NH} \_2 \mathrm{H}$ & $1 \mathrm{E}-4$ & 0.63 & 0.30 & $3 \mathrm{E}-4$ & 0.53 & 0.36 & $8 \mathrm{E}-4$ & 0.57 & 0.61 \\
\hline $2 \mathrm{~N} \mathrm{NH}{ }_{2} \mathrm{H}$ & 20. & -0.07 & -0.39 & 21.7 & -0.17 & -0.31 & 64.5 & -0.14 & -0.09 \\
\hline $2 \mathrm{~N} \mathrm{NH}_{3}$ & $5 \mathrm{E}-5$ & 0.69 & 0.39 & $8 \mathrm{E}-5$ & 0.61 & 0.47 & $4 \mathrm{E}-4$ & 0.61 & 0.68 \\
\hline $2 \mathrm{~N}$ & $2 \mathrm{E}-4$ & 0.61 & 0.11 & $1 \mathrm{E}-3$ & 0.62 & 0.47 & $2 \mathrm{E}-5$ & 0.82 & 0.88 \\
\hline $4 \mathrm{~N}$ & 0.22 & 0.20 & -1.10 & $2 \mathrm{E}-2$ & 0.28 & -0.80 & 0.092 & 0.27 & -0.80 \\
\hline $3 \mathrm{~N} N H$ & $4 \mathrm{E}-3$ & 0.57 & -0.65 & $1 \mathrm{E}-4$ & 0.57 & -0.43 & $8 \mathrm{E}-4$ & 0.57 & -0.41 \\
\hline $2 \mathrm{~N} \_2 \mathrm{H} \_$lin & 53.6 & -0.12 & -0.63 & 61.1 & -0.24 & -0.41 & 11.4 & -0.03 & 0.02 \\
\hline $2 \mathrm{~N} 2 \mathrm{H}$ & 16.9 & -0.06 & -0.56 & 10.4 & -0.13 & -0.24 & 1.96 & 0.08 & 0.19 \\
\hline $2 \mathrm{~N}-\mathrm{NH}_{3} \mathrm{H}$ & $3 E-3$ & 0.45 & 0.24 & $5 \mathrm{E}-2$ & 0.21 & 0.05 & 0.19 & 0.23 & 0.26 \\
\hline $2 \mathrm{~N} H$ & $5 \mathrm{E}-2$ & 0.29 & -0.22 & $2 \mathrm{E}-2$ & 0.25 & 0.10 & $5 \mathrm{E}-3$ & 0.46 & 0.52 \\
\hline $2 \mathrm{~N} N \mathrm{NH} 2 \_2 \mathrm{H}$ & 1.6 & 0.08 & -0.30 & 5.0 & -0.08 & -0.22 & 13.2 & -0.04 & 0.03 \\
\hline $\begin{array}{l}\mathrm{kMC} \text { theory } \\
\mathrm{NH}_{3} \\
\mathrm{~mol} / \mathrm{s} /(2 \times 2)\end{array}$ & \multicolumn{3}{|c|}{17.7} & \multicolumn{3}{|c|}{93.7} & \multicolumn{3}{|c|}{18.6} \\
\hline $\begin{array}{l}\text { Experiment } \\
{ }^{13} \mathrm{NH}_{3} \\
\mathrm{~mol} / \mathrm{s} /(2 \mathrm{x} 2)\end{array}$ & \multicolumn{3}{|c|}{9.7} & \multicolumn{3}{|c|}{ N/A } & \multicolumn{3}{|c|}{ N/A } \\
\hline $\begin{array}{l}\text { total } \\
\mathrm{NH}_{3} \mathrm{~mol}\end{array}$ & \multicolumn{3}{|c|}{48482} & \multicolumn{3}{|c|}{33764} & \multicolumn{3}{|c|}{2529} \\
\hline $\begin{array}{l}3 \mathrm{~N} \mathrm{NH}_{3} \mathrm{H} \\
\leftrightarrow 3 \mathrm{NH}\end{array}$ & \multicolumn{3}{|c|}{24262} & \multicolumn{3}{|c|}{16801} & \multicolumn{3}{|c|}{1284} \\
\hline $\begin{array}{l}2 \mathrm{~N}_{-} \mathrm{NH}_{3-} \mathrm{H} \\
\leftrightarrow 2 \mathrm{~N} H\end{array}$ & \multicolumn{3}{|c|}{24220} & \multicolumn{3}{|c|}{16963} & \multicolumn{3}{|c|}{1245} \\
\hline
\end{tabular}

Table 2. Top rows - Per cent of populations (i.e., residence times) $=t_{i}(\%)$, apparent free energy differences [evaluated as minus the logarithm of ratio of populations $=\mathrm{P}_{\mathrm{i}} / \mathrm{P}_{0}$, where $\mathrm{P}_{0}=\mathrm{P}_{3 \mathrm{~N} \mathrm{NH} 2}$, and thermodynamic free energy differences $(\Delta \mathrm{G})$ for selected configurations in a $\mathrm{Fe}(111)-(2 \times 2)$ unit cell under steady-state of ammonia synthesis as predicted by $\mathrm{kMC}$ simulations at different temperatures $\left(673\right.$ and $730 \mathrm{~K}$ ), and different $\mathrm{H}_{2}, \mathrm{~N}_{2}, \mathrm{NH}_{3}$ pressures using data from DFT/PBE- 
D3. All configurations are assumed in the zig-zag arrangement, except for " $2 \mathrm{~N} \_2 \mathrm{H}$ lin" which is linear (see SI for details). Temperature in Kelvin, pressure in atmospheres, free energy differences in $\mathrm{eV}$. Bottom rows $-\mathrm{NH}_{3}$ molecules produced per second per $(2 \times 2)$ unit cell under the given conditions $\left[\mathrm{NH}_{3} \mathrm{~mol} / \mathrm{s} /(2 \times 2)\right.$ : the conversion factor to moles per second per $\mathrm{cm}^{2}$ in $\mathrm{ref}^{13}$ is $3 \times 10^{-10}$ ], total number of $\mathrm{NH}_{3}$ molecules produced in the $\mathrm{kMC}$ runs (total $\mathrm{NH}_{3} \mathrm{~mol}$ ), further partitioned into the 2 main steps involving $\mathrm{NH}_{3}$ adsorption/desorption: $3 \mathrm{~N}_{-} \mathrm{NH}_{3} \mathrm{H} \leftrightarrow 3 \mathrm{~N} \_\mathrm{H}$; $2 \mathrm{~N}_{-} \mathrm{NH}_{3} \_\mathrm{H} \leftrightarrow 2 \mathrm{~N} \_\mathrm{H}$.

\section{Comparison with previous literature}

\subsection{Comparison with experiment}

In the above discussions we compared our predicted TOF with the single crystal experimental values (Somorjai), finding excellent agreement.

Another comparison in with experiment is to Temperature Programmed Desorption (TPD) in which a monolayer (ML) of $\mathrm{NH}_{3}$ at low temperature is heated at a uniform rate $\mathrm{dT} / \mathrm{dt}$ and the products measured with a mass spectrometer. Here the temperature for the peak desorption rate, TPD peak, combined with dT/dt in the Redhead equation gives a crude estimate of the binding energy. Our predicted binding energies are consistent with available experimental literature. Thus, Figure 9 of Strongin et $\mathrm{al}^{13}$ reports TPD experiments on $\mathrm{Fe}(111)$ with a very broad desorption peak centered at about $300{ }^{\circ} \mathrm{K}$ for a heating rate of $8^{\circ} \mathrm{K} / \mathrm{sec}$, which corresponds to an activation barrier for desorption of $0.82 \mathrm{eV}$. This compares well with the values of 0.89 to 1.00 $\mathrm{eV}$ we calculate for the $\mathrm{NH}_{3}$ desorption barrier.

Our results are also consistent with experiments conducted on polycrystalline Fe wires by Ertl and Huber ${ }^{46-47}$ At $\mathrm{T}=673^{\circ} \mathrm{K}$ our barriers for $\mathrm{NHx}$ dehydrogenation mechanisms $(\mathrm{NHx} \rightarrow \mathrm{NHx}-1$ $+\mathrm{H})$ range from 0.53 to $0.63 \mathrm{eV}$ which are lower than the barrier for $\mathrm{NH}_{3}$ desorption $(0.76$ to $0.87 \mathrm{eV}$ ) which in turn are lower than the barrier for both $\mathrm{N}_{2}$ dissociation $(1.27 \mathrm{eV})$ and for $\mathrm{N}$ adatom recombination $(2.04 \mathrm{eV})$. Our predicted $\mathrm{NH}_{3}$ sticking coefficient at $673{ }^{\circ} \mathrm{K}$ and a $\mathrm{NH}_{3}$ pressure of $5 \times 10^{-6}$ torr is about 5 times larger than the $\mathrm{N}$-adatom recombination rate (the kinetic constant corresponding to our $2.04 \mathrm{eV}$ barrier is $0.03 \mathrm{sec}-1$ ), which should be contrasted with a near equality at $\mathrm{T}>640{ }^{\circ} \mathrm{K}$ in previous study. ${ }^{46}$. However, the Ertl experiments ${ }^{46-47}$ were on $\mathrm{Fe}$ polycrystalline wires in which the presence of (100) and (110) facets may increase the ratio of Nadatom recombination over the $\mathrm{NH}_{3}$ dissociative sticking rate. Indeed the experimentally derived value of $45 \pm 5 \mathrm{kcal} / \mathrm{mol}$ for the activation free energy of $\mathrm{N}$-adatom recombination in literature. ${ }^{46-}$ 47 is only slightly lower than our predicted value of $47 \mathrm{kcal} / \mathrm{mol}(2.04 \mathrm{eV})$. Our value is also slightly lower than the experimental value of $51 \mathrm{kcal} / \mathrm{mol}$ reported on $\mathrm{Fe}(111)$ by Bozso et al. ${ }^{48}$ (At 1 torr $\mathrm{NH}_{3}$ we predict an adsorption kinetic constant of $3 \times 10^{4}$ on the $2 \mathrm{~N}$ site.)

Another TPD experiment on industrial catalysts ${ }^{49}$ observed a $\mathrm{N}_{2}$ desorption peak at $644^{\circ} \mathrm{K}$, with an estimated $\mathrm{N}$-adatom recombination rate of $1-2 \times 10^{9} \times \exp (-146 \mathrm{~kJ} / \mathrm{mol} / \mathrm{RT})$. This rate corresponds to an apparent free energy barrier at $644{ }^{\circ} \mathrm{K}$ of $\Delta \mathrm{G}=2.00$ to $2.04 \mathrm{eV}$, which is very close to our predicted barrier of $2.04 \mathrm{eV}$ at $\mathrm{T}=673{ }^{\circ} \mathrm{K}$, especially considering that the industrial catalyst is K-promoted and hence is expected to exhibit a smaller barrier. In the same work, the $\mathrm{N}$-adatom coverage under Haber-Bosch reaction conditions was estimated to be 0.4 of the maximum $\mathrm{N}$-adatom coverage under $\mathrm{N}_{2}+3 \mathrm{H}_{2}$ conditions, a value close to our predicted value of 0.5 for the $2 \mathrm{~N} . \mathrm{xH}$ configurations predominant on the $(2 \times 2)$ unit cell. 


\subsection{Comparison with theory}

\section{2a Norskov studies}

The pioneering QM study for Haber Bosch chemistry on Fe(111) was reported in 1999 by Nørskov et $a 1^{50}$. They investigated in detail several states with $\mathrm{N}_{2}$ molecularly adsorbed and/or dissociated and considered simplified pathways for dissociation. Their qualitative picture considers $\mathrm{N}_{2}$ dissociation as the RDS, which we have shown to be correct with our detailed reaction kinetics based on QM free energies and reaction barriers. However, there are significant quantitative differences because we calculated reaction barriers, whereas they examined only stable species. Instead they made estimates using the Ulitsky-Elber approximation to find minimum energy paths. In contrast we used fully relaxed NEB techniques. In addition Nørskov et.al ${ }^{50}$ used the rev-PBE $\mathrm{xc}$-functional without dispersion corrections (dispersion corrections increase adsorption energies by $\sim 10 \%$ ). They used a slab with 7 layers apparently relaxed without constraints (compared to 6 in ours), but with a very small (1x1) unit cell or sometimes sqrt(3) $x$ sqrt(3), rather than the $2 \times 2$ used in our studies. Also entropic corrections to free energies were not included in their calculations.

Nørskov et al. ${ }^{50}$ considered dissociatively chemisorbed binding energies for $\mathrm{N}_{2}$ and described several states labeled as $\alpha, \alpha^{\prime}, \delta, \beta, \gamma$. We used PBE-D3 to calculate the binding energies for these states with the results in table S1 of the SI. We found much stronger binding for both horizontally and vertically chemisorbed $\mathrm{N}_{2}$ states $\alpha, \alpha^{\prime}, \delta, \beta$, due to a better description of dispersion correction. We also found that $\mathrm{N}_{2}$ adsorption states have a very sensitive adsorption energy dependence with respect to the surface's $\mathrm{N}$ atom coverage. State $\alpha$ is better in electronic energy of $\sim 0.2 \mathrm{eV}$ than $\alpha^{\prime}$ on bare surface, however, with $2 \mathrm{~N}$ present on the surface, the result is reversed and state $\alpha^{\prime}$ is better in energy than $\alpha$ by $\sim 0.2 \mathrm{eV}$. We arrived at similar result for dissociated $\mathrm{N}$ atom.

However, despite some differences in the specific numbers, we confirmed the Nørskov overall pathway for dissociate chemisorption of N2. Triple-bonded $\mathrm{N}_{2}$ adsorbed on first layer $(\gamma) \Rightarrow$ triple-bonded $\mathrm{N}_{2}$ adsorbed on second layer $(\delta) \Rightarrow$ double-bonded $\mathrm{N}_{2}$ bonded to a bridging site $(\alpha)$ $\Rightarrow>$ single-bonded $\mathrm{N}_{2}$ bonded to a three-fold site $\left(\alpha^{\prime}\right) \Rightarrow$ dissociated $\mathrm{N}$ atoms $(\beta)$. The biggest difference is that our calculations have two other $\mathrm{N}$ already bonded to 4 -fold sites, which changes the overall energetics and barriers.

\section{2b Lin studies}

A more recent $\mathrm{QM}$ study on adsorption and dissociation of $\mathrm{NH}_{3}$ molecule on $\mathrm{Fe}(111)$ by Lin et.al $^{41}$ provided comprehensive adsorption energy data for several species, including $\mathrm{N}, \mathrm{H}, \mathrm{NH}$, $\mathrm{NH}_{2}$, and $\mathrm{NH}_{3}$. They used a revised Perdew-Burke-Ernzerhof (GGA-rPBE) exchange correlation functional, without dispersion corrections. They used a $(3 \times 3)$ unit cell, compared to our $(2 \times 2)$ cell. They calculated QM barriers but did not calculate the activation free energies for reactions. The influence of coverage on adsorption energy was not considered, nor were entropic corrections to free energies calculated. Their results in $\mathrm{kcal} / \mathrm{mol}$, are converted to $\mathrm{eV}$ in table $\mathrm{S} 1$ of the SI. This study by Lin et.al ${ }^{41}$ leads to better agreement for binding of $\mathrm{N}, \mathrm{NH}, \mathrm{NH}_{2}$ (after correcting for the difference in surface coverage). It is expected that their adsorption energies would be $\sim 30 \%$ too weak due to the lack of D3 dispersion corrections.

\section{Summary and conclusions}


We report here the first comprehensive study of the mechanisms underlying $\mathrm{NH}_{3}$ synthesis by $\mathrm{Fe}$ based catalysts including the reaction barriers for all 17 steps involved and considering both Langmuir-Hinshelwood (surface species reacting with surface species) and Eley-Rideal (gas phase species reacting with surface species) processes.

The QM was at the level of PBE including D3 London dispersion (van der Waals attraction) corrections that was previously applied successfully to the oxygen reduction reaction $\left(\mathrm{O}_{2}+\right.$ protons $\rightarrow \mathrm{H}_{2} \mathrm{O}$ ) on $\mathrm{Pt}$ and the $\mathrm{CO}_{2}$ and $\mathrm{CO}$ reduction reactions on $\mathrm{Cu}$ surfaces. ${ }^{17-21,23-25}$

Correcting the DFT for phonons to get free energies at experimental reaction conditions, and carrying out extensive kinetic Monte Carlo calculations to obtain the steady state populations at the conditions of the single crystal experiments $\left(673^{\circ} \mathrm{K}, 15\right.$ atm $\mathrm{H}_{2}, 5$ atm $\mathrm{N}_{2}$, and 1.5 torr $\left.\mathrm{NH}_{3}\right)$ leads to a predicted TOF=17.7 sec-1 per $2 \times 2 \mathrm{Fe}(111)$ surface site, in excellent agreement with the single crystal experimental rate of $\mathbf{T O F}=9.7 \mathrm{sec}-1$ per site. This suggests that the accuracy of PBE-D3 for the critical barriers may be of the order of $0.04 \mathrm{eV}$.

This overall agreement in the predicted TOF with experiment indicates that the QM combined with $\mathrm{kMC}$ provides a new detailed understanding of the reaction mechanism underlying $\mathrm{NH}_{3}$ synthesis. This should provide a basis for considering how to modify the catalyst to improved performance. In particular, the changes in the spins and charges in the TS provides hints, as discussed above of considering alloying with metals having localized spins, such as $\mathrm{Cr}, \mathrm{Mn}, \mathrm{Co}$, or $\mathrm{Ni}$, or with metals not expected to have localized spins such as $\mathrm{Ru}$ or Os.

Despite the excellent agreement, we should caution that the experiments might have been affected by impurities such as $\mathrm{O}$ that might affect the rates. Also the QM calculations using the phonons to predict free energies at reaction conditions might miss dynamical and anharmonic effects that would require quantum based reaction dynamics. Moreover, the limitation to a $2 \mathrm{x} 2$ unit cell may eliminate some reactions that could require larger unit cells. In addition, replacing the PBE level of DFT might be important for a system such as this with localized spins and the origin of the D3 corrections for London dispersion is suspect.

\section{Associated content}

Supporting Information. Energy landscape and kinetic Monte Carlo results for Haber Bosch reaction at PBE level; transition state geometry and potential energy curves for key processes; pictorial illustration of "linear" and "zig-zag" configurations; detailed instructions on the use of the excel file with full numerical data (PDF). Numerical data of electronic energies and free energies for surface configurations using PBE-D3 and PBE xc-functionals at $673{ }^{\circ} \mathrm{K}$ and $730{ }^{\circ} \mathrm{K}$, thermodynamic data for gas-phase molecules, and reaction energy barriers for key processes, reported in a 4-sheet excel file (XLSX).

\section{Acknowledgements}

This work was supported by the U.S. Department of Energy (USDOE), Office of Energy Efficiency and Renewable Energy (EERE), Advanced Manufacturing Office Next Generation R\&D Projects under contract no. DE-AC07-05ID14517 (program manager Dickson Ozokwelu, in collaboration with Idaho National Labs, Rebecca Fushimi). This project was initiated with modest support from the U.S. Department of Energy's Advanced Research Projects AgencyEnergy (ARPA-E) under contract number DE-AR0000552 (Patrick McGrath) aimed at examining novel methods for accelerating catalytic reactions. 
A.F. gratefully acknowledges financial support from a Short-Term Mission (STM) funded by ItalianConsiglio Nazionale delle Ricerche (CNR).

We thank Dr. Tao Cheng for help with the ER reaction for $\mathrm{N}_{2}$ dissociation.

Many of the calculations were carried out on a GPU-cluster provided by DURIP (Cliff Bedford, program manager). This work used the Extreme Science and Engineering Discovery Environment (XSEDE), which is supported by National Science Foundation grant number ACI1548562. 


\section{References}

(1) Erisman, J. W.; Sutton, M. A.; Galloway, J.; Klimont, Z.; Winiwarter, W. Nat. Geosci. 2008, 1, 636639.

(2) Schlögl, R. Angew. Chem. Int. Ed. 2003, 42, 2004-2008.

(3) Mittasch, A.; Frankenburg, W. Adv. Catal. 1950, 2, 81-104.

(4) Hara, M.; Kitano, M.; Hosono, H. ACS Catal. 2017, 7, 2313-2324.

(5) Nielsen, A. Ammonia: Catalysis and Manufacture; Springer: Heidelberg, 1995.

(6) Hellman, A.; Honkala, K.; Remediakis, I. N.; Logadóttir, Á.; Carlsson, A.; Dahl, S.; Christensen, C. H.; Nørskov, J. K. Surf. Sci. 2009, 603, 1731-1739.

(7) Kitano, M.; Kanbara, S.; Inoue, Y.; Kuganathan, N.; Sushko, P. V.; Yokoyama, T.; Hara, M.; Hosono, H. Nat. Commun. 2015, 6.

(8) Rossetti, I.; Pernicone, N.; Forni, L. Appl. Catal. Gen. 2001, 208, 271-278.

(9) Akinfieva, T. A. Gig. Tr. Prof. Zabol. 1981, No. 1, 46-47.

(10) Jennings, J. R., Ed. Catalytic Ammonia Synthesis; Plenum: New York, 2013.

(11) Norton P. R. The Chemical Physics of Solid Surfaces and Heterogeneous Catalysis; King, D. A., Woodruff, D. P., Eds.; Elsevier: Amsterdam, 1982; Vol. 4.

(12) Ertl, G.; Knoezinger, H. Handbook of Heterogeneous Catalysis, 5 Volume Set; Wiley-VCH: Weinheim, Germany, 2008

(13) Somorjai, G. A.; Materer, N. Top. Catal. 1994, 1, 215-231.

(14) Strongin, D. R.; Carrazza, J.; Bare, S. R.; Somorjai, G. A. J. Catal. 1987, 103, 213-215.

(15) Johnson, E. R.; Becke, A. D. J. Chem. Phys. 2006, 124, 174104.

(16) Grimme, S.; Antony, J.; Ehrlich, S.; Krieg, H. J. Chem. Phys. 2010, 132, 154104.

(17) Cheng, T.; Goddard, W. A.; An, Q.; Xiao, H.; Merinov, B.; Morozov, S. Phys. Chem. Chem. Phys. 2017, 19, 2666-2673.

(18) Cheng, T.; Xiao, H.; Goddard, W. A. Proc. Natl. Acad. Sci. U. S. A. 2017, 114, 1795-1800.

(19) Cheng, T.; Xiao, H.; Goddard, W. A. J. Phys. Chem. Lett. 2015, 6, 4767-4773.

(20) Cheng, T.; Xiao, H.; Goddard, W. A. J. Am. Chem. Soc. 2016, 138, 13802-13805.

(21) Cheng, T.; Xiao, H.; Goddard, W. A. J. Am. Chem. Soc. 2017, 139, 11642-11645.

(22) Ping, Y.; Nielsen, R. J.; Goddard, W. A. J. Am. Chem. Soc. 2017, 139, 149-155.

(23) Xiao, H.; Cheng, T.; Goddard, W. A. J. Am. Chem. Soc. 2017, 139, 130-136.

(24) Xiao, H.; Cheng, T.; Goddard, W. A.; Sundararaman, R. J. Am. Chem. Soc. 2016, 138, 483-486.

(25) Xiao, H.; Goddard, W. A.; Cheng, T.; Liu, Y. Proc. Natl. Acad. Sci. U. S. A. 2017, 114, 6685-6688.

(26) Kresse, G.; Furthmüller, J. Phys. Rev. B 1996, 54, 11169-11186.

(27) Perdew, J. P.; Burke, K.; Ernzerhof, M. Phys. Rev. Lett. 1996, 77, 3865-3868.

(28) Perdew, J. P.; Burke, K.; Ernzerhof, M. Phys. Rev. Lett.. 1997, 78, 1396-1396.

(29) Stephens, P. J.; Devlin, F. J.; Chabalowski, Cf.; Frisch, M. J. J. Phys. Chem. 1994, 98, 11623-11627.

(30) Malcolm, W., Chase, J., Eds.; NIST-JANAF Thermochemical Tables, 4th ed. J. Phys. Chem. Ref. Data 1998.

(31) Kittel, C. Introduction to Solid State Physics; Wiley: New York, 1996.

(32) McClurg, R. B.; Flagan, R. C.; Goddard III, W. A. J. Chem. Phys. 1997, 106, 6675-6680.

(33) Campbell, C. T.; Sprowl, L. H.; Árnadóttir, L. J. Phys. Chem. C 2016, 120, 10283-10297.

(34) Redondo, A.; Zeiri, Y.; Goddard III, W. A. Phys. Rev. Lett. 1982, 49, 1847.

(35) Henkelman, G.; Uberuaga, B. P.; Jónsson, H. J. Chem. Phys. 2000, 113, 9901-9904.

(36) Henkelman, G.; Jónsson, H. J. Chem. Phys. 1999, 111, 7010-7022.

(37) Heyden, A.; Bell, A. T.; Keil, F. J. J. Chem. Phys. 2005, 123, 224101(.

(38) Grunze, M.; Bozso, F.; Ertl, G.; Weiss, M. Appl. Surf. Sci. 1978, 1, 241-265.

(39) Hsiao, M.-K.; Su, C.-H.; Liu, C.-Y.; Chen, H.-L. Phys. Chem. Chem. Phys. 2015, 17, 30598-30605. 
(40) Satoh, S.; Fujimoto, H.; Kobayashi, H. J. Phys. Chem. B 2006, 110, 4846-4852.

(41) Lin, R.-J.; Li, F.-Y.; Chen, H.-L. J. Phys. Chem. C 2010, 115, 521-528.

(42) Kua, J.; Goddard, W. A. J. Phys. Chem. B 1998, 102, 9481-9491.

(43) Kua, J.; Goddard, W. A. J. Phys. Chem. B 1998, 102, 9492-9500.

(44) Kua, J.; Faglioni, F.; Goddard, W. A. J. Am. Chem. Soc. 2000, 122, 2309-2321.

(45) Kua, J.; Goddard, W. A. J. Am. Chem. Soc. 1999, 121, 10928-10941.

(46) Ertl, G.; Huber, M. J. Catal. 1980, 61, 537-539.

(47) Ertl, G.; Huber, M.; Lee, S. B.; Paal, Z.; Weiss, M. Appl. Surf. Sci. 1981, 8, 373-386.

(48) Bozso, F.; Ertl, G.; Grunze, M.; Weiss, M. J. Catal. 1977, 49, 18-41.

(49) Muhler, M.; Rosowski, F.; Ertl, G. Catal. Lett. 1994, 24, 317-331.

(50) Mortensen, J. J.; Hansen, L. B.; Hammer, B.; Nørskov, J. K. J. Catal. 1999, 182, 479-488. 
Table of Contents figure

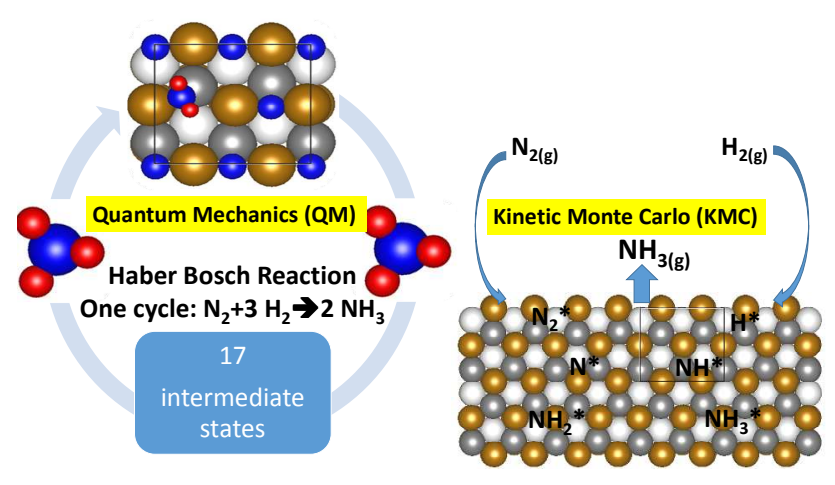

